\title{
アルミナ磁器と鉄・モリブデン合金の焼結接合
}

\author{
安藤 汀 \\ 啝日本特殊陶業 棇合研究所, $\mathbf{T} 485$ 小牧市大字岩猗 2808.
}

\section{Sinter-bonding of Alumina Ceramic onto Iron-Molybdenum Alloy}

\author{
Minato Ando \\ R\&D Department, NGK Spark Plug Co., Ltd., 2808 Iwasaki, Komaki 485.
}

Received May 27, 1996

\section{SWOPSIS}

Joinning ceramic to metal without interlayer was tried using process from emulsifying of suspension to sintering. Alumina-kerosene suspension (0) was mixed wi th iron oxide-molybdenum-water suspension $(W)$ and (W/0) emulsion was formed. Af ter casting the emulsion, the ( $W$ ) particles submerged to bottom due to difference in density between (0) and $(W)$. The dried body was sintered in a reducing atmosphere and transformed to double layer consisting of alumina ceramic and iron-molybdenum alloy. At the area between these layers, protrusions of the alloy were locked in the alumina ceramic and this was considered to be a source of joint strength.

\section{KEY HORDS}

joinning, emulsion, alumina, interlayer, alloy.

\section{1 緒 言}

セラミックと金属との接合には各㮔の手法か椆発され ているが，通常，両者の間に遣移首あるいは固溶体や化 合物等の中間居か价在した，拡散接合法が多用されてい る.ここの接合法は，あらかじめ用意された，金属とセう ミックあるいは，それぞれの粉末成形体を，接合用材を 介して接触させ，熱迈理することを基本プロセスとして いる. したがって，接合面䅪が大きく溥手のものになる 程，平坦て接合むらのないものを得ることが容易てなく なる. 本研究では，熟路張率の近做したセラミックと金

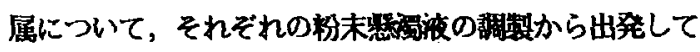
両者の混合乳化，キャスティング成形，そして烧結に至

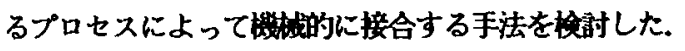

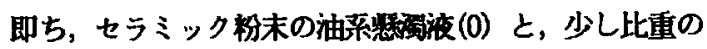

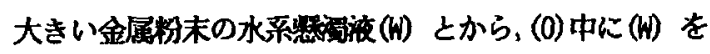
乳化分散させた乳泡液（W/0) を調制してこれをキャステ イングした. 比重差て，(W) 精子は(0) 内を俆々に湖降 し，ほほ（W）と(0)に分噰した棈造の成形体とした後に

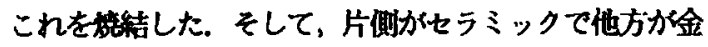
属から成り，両者の境界部ては，マトリックスのセラミ ックが，突出した金属部を街え込む，中間局を介在させ ない烧結接合体の作製を試みた。

\section{2 試手およU夷了方法}

\section{1 使用原料}

セラミック粉末には，アルミナを虺択した，金属材料 
には，熱䎔張率と烧結温度をアルミナにマッチさせるた め，モリブデンと鉄の混合粉末を用いることにしたしし かし，鉄については，微細な粉末が手し難いため，酸 化第一鉄 $(\mathrm{Fe}$ 0) を用いた．これら粉末の特性を Table 1 に示す。

Table 1 Properties of powder used in this study

\begin{tabular}{lccc}
\hline Powder & Purity & $\begin{array}{l}\text { Specific surface } \\
\text { area } \\
\left(\mathrm{m}^{2} \mathrm{Kg}^{-1}\right)\end{array}$ & $\begin{array}{l}\text { Particle } \\
\text { size } \\
(\mathrm{m})\end{array}$ \\
\hline $\mathrm{Al}_{2} \mathrm{O}_{3}$ & $99.95 \%$ & $11 \times 10^{3}$ & $0.2 \times 10^{-6}$ \\
$\mathrm{Mo}$ & 99.9 & $1.1 \times 10^{3}$ & $2.3 \times 10^{-6}$ \\
$\mathrm{Fe} 0$ & $\mathrm{CP}$ & $2.1 \times 10^{3}$ & $1.2 \times 10^{-6}$ \\
\hline
\end{tabular}

$\mathrm{CP}:$ chemical pure

\section{2 㦟淈液の調製}

油系の愁摆液 (0) は，予めシランカップリング処理し て親油性を高めたアルミナ $6 \times 10^{-2} \mathrm{Kg}$ に白灯油 $1 \times 10^{-4}$ $\mathrm{m}^{3}$ を加え，ボールミルで15時間混合し調製した. 水系の

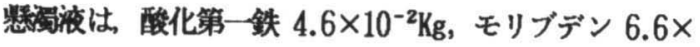
$10^{-2} \mathrm{Kg}$, ポリビニルアルコ-ル $4 \times 10^{-3} \mathrm{Kg}$, 水 $4 \times 10^{-5}$ $\mathrm{m}^{3}$ を加え, 15 時間ボー ルミル混合して (W) を調製した. （0）と(W) の比重は,それぞれ1.22,1.83 と，(W)を大き く設定した。

\section{3 乳嘱液の調製とキャスティング}

容量 $3 \times 10^{-4} \mathrm{~m}^{3}$ のガラスビ- カに(0) を移し, $800 \mathrm{rpm}$

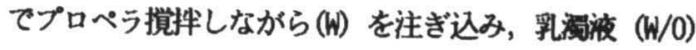
を調製した.この乳涯液をポリ塩化ビニルフィルムの上 にキャスティングした後, 室温て 7日間, 排風室に放置 して乾媬した.

\section{4 蜕成}

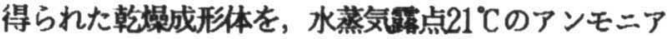
分解ガス中, $1480{ }^{\circ} \mathrm{C} て 1.5$ 時間烧成した.

\section{1 乾焻体の構造}

Photo.1 に，キャスティング乾娼体断面の上半部を示 す. 酸化第一鉄とモリブデンの混合枌体か，径(8-30)・ $10^{-5} \mathrm{~m}$ の球体から棈円体に形状変化しながら, 下方に沈 降している様子か班想められる. しかし，沈降か十分進行 しているとは言い難い。これは, 生成乳源液(W/0) が,
キャスティング後に塑性流動化してきたことによるもの と考えられる. 又, 下方程 榇円体の倡平化か進行して いるのは，(W）の眖水乾焻過程ての上部からの王迫荷重 が，下方ほど大きくなったためと推测される.

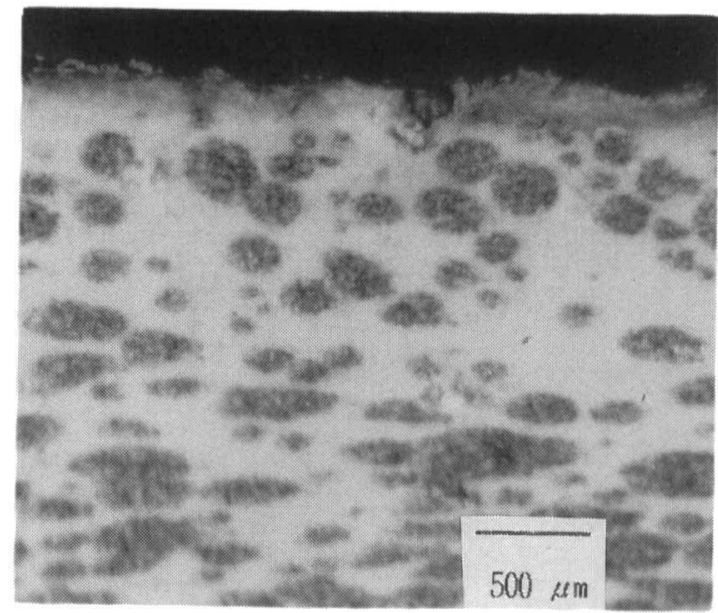

Photo.1 Optical micrograph of cross section of casted specimen.

\section{2 蜕結体の構造}

Photo.2 に，アルミナ磁器居を上面にした焼結体の外 観を示す. Photo. 3 に, 烧結体の断面を示すか，上部に アルミナ磁器居か形成されており, 金属球の混入も認め られる. 下部では，榇円体状をなして沈樍した金属粉塊 が続結して金属居を形成している. 斜めにした应大断面 部をPhoto.4 に示す. 磁器居と金属居の境界で, 両者 がかなり入り乱れた状態にあるが，基本的には娆結金属 の数珠状突出部が，マトリックス相のアルミナ磁器に衡 え込まれた粎相を呈している. 又, 金属居内の所々にマ トリックス相であったアルミナ磁器力閉じ込められてい るのが綛められる. 烧結体破面の, 磁器相と金属相との 境界部の微構造をPhoto. 5 に示す. 左側の金属相は娆結 が進展しており，結晶組成は X線回折测定により，Fello が主体て他に少量のFe 3 Mo, MoN か唯䙡された. 右側のセ ラミック相には紋密化の余地か牫されている. これは, カップリング姏理で結合したシランから烧成時に誘迹さ れた $\mathrm{Si}_{2}$ がアルミナの十分な烧結を抑制したものと考え られる6! 磁器相と金属相の領域は明眖に区画され, 両者 の境界に中間居らしきものは認められない，境界の榢間 は，成形体における，金属枌体部とセラミック枌体部と の㮠結収縮率の違いと，烧結後の，金属部と磁器部との 


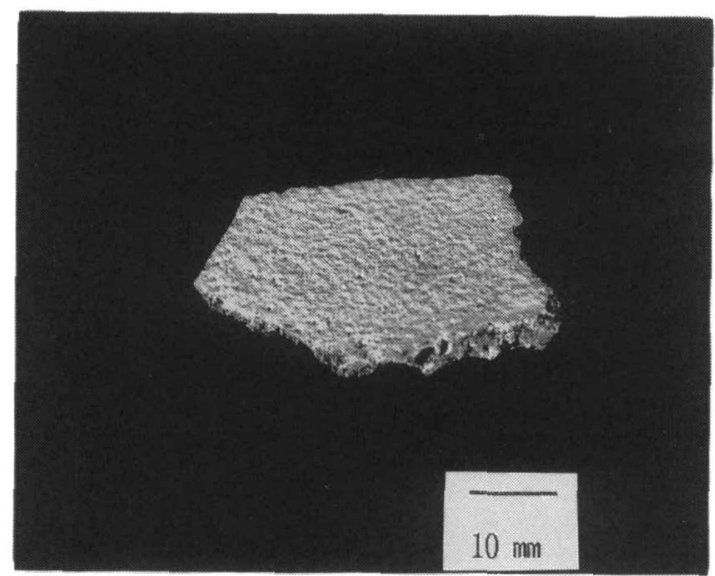

Photo.2 Appearance of sintered specimen.

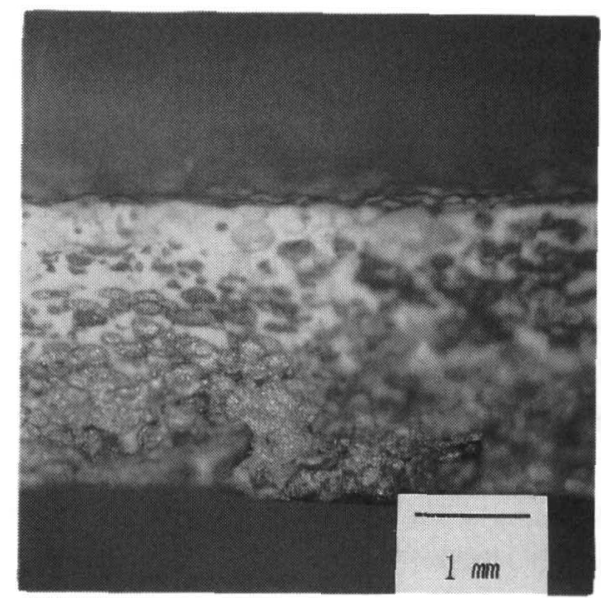

Photo.3 0ptical micrograph of cross section of sintered specimen.

冷却収縮率の違いの二つに影響される. Photo.5 の倍率 を下げたものを,Photo.6に示すが，左侧と右上の境界部 のアルミナ磁器側に, 長さ $(2-3) \cdot 10^{-5} \mathrm{~m}$ の癿裂力惥め られる. この蹧裂は, 続結後の掵却過程で, 引っ張り応 カがアルミナ磁器に働いた結果と考えられ、アルミナ磁 器の朎却収縮が，鉄・モリブデン合金より若干大きかっ たことを示す. 金属屏の表面部をPhoto.7 に示す.モリ ブデンと酸化第一鉄の混合粉体か，乳化粒子の単位で沈 積したものを焼結して形成された金属居の表面部にも, マトリックス相であったアルミナ磁器の混在が蟌められ る.

\section{3 接合強度}

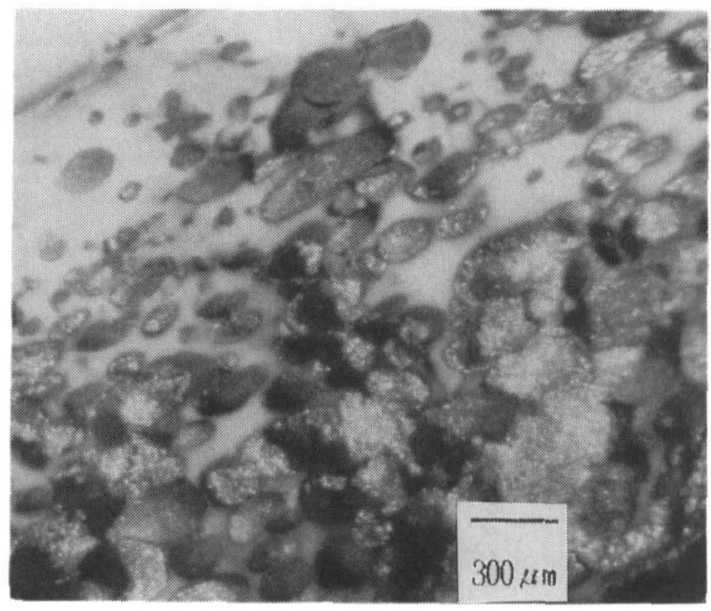

Photo.4 Magnified optical micrograph of cross section of sintered specimen.

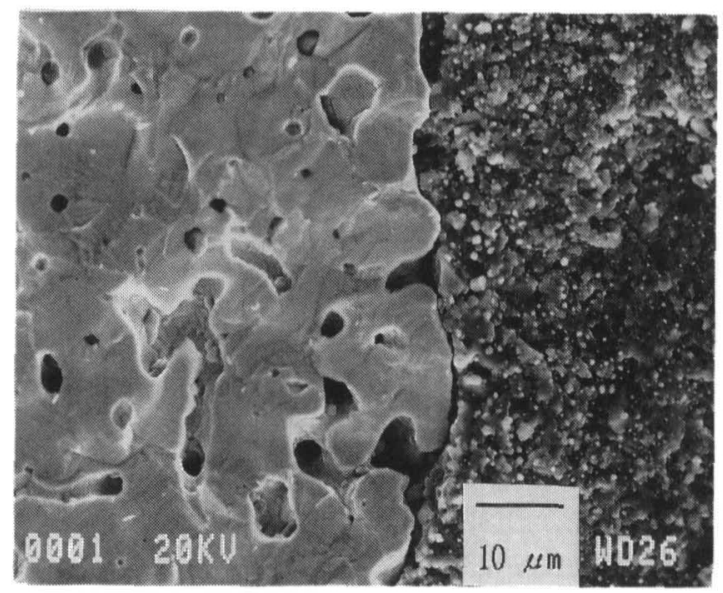

Photo.5 SEM image of boundary region between $\mathrm{Fe} / \mathrm{Mo}$ alloy and alumina ceramic.

焼結体の禹面に，引っ張り金具を接着剂で取り付け， 接合強度を测定したか，接着面で金具が剥解したため, 剝踓強度である $9.2 \times 10^{5} \mathrm{Kgm}^{-2}$ 以上であると推定でき るに留まった。

\section{4 まとめ}

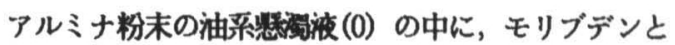
酸化第一鉄の混合粉末の水系紫清液（W）を乳化分散させ た乳淘液をキャスティングした，そして，比重差で(W)

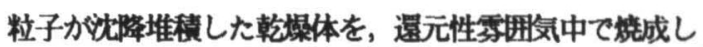
て磁器と金属との烧結接合体の作製を試み, 以下の結果 を得た。 


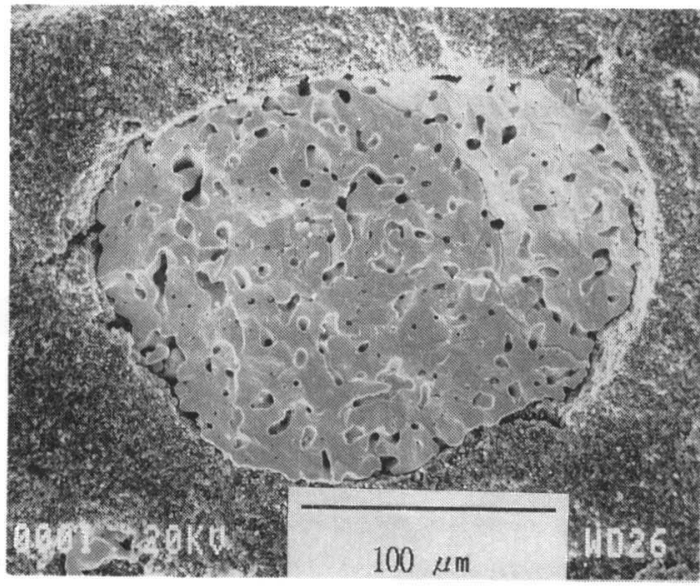

Photo. 6 Reduced image of photo. 5 .

1）(0)内を, (W) 粒子か沈降堆積した構造の成形体を烧結 することにより，アルミナ磁器と，鉄・モリブデン合金 の皘居焼結体力得られた．しかし，金属粉体か乳化粒子

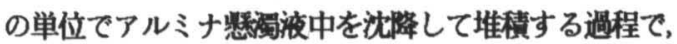
アルミナ粉体の一部が上記乳化粒子間の腺間に閉じ込め られた結果，焼結体の，鉄・モリブデン合金居の内部に は，アルミナ磁器が分散混入した，又，アルミナ磁器居 には，沈降しきれなかった乳化金属粒子が，鉄・モリプ デン合金球として混入した。

2）マク口的には，磁器居と合金居の境界部て，烧結金 属の突出部か嗞器に銜え込まれた構造が形成された。 ク口的には，アルミナ磁器相と，鉄・モリブデン合金相 の領域は明瞭に区画され、境界部に中間居は存在しなか った，アルミナ磁器居と，鉄・モリブデン合金居との機 械的接合力は，このマク口構造によるものと考える. 3）アルミナ磁器層と，鉄・モリブデン合金層との接合 強度は $9.2 \times 10^{5} \mathrm{Kgm}^{-2}$ 以上であった。

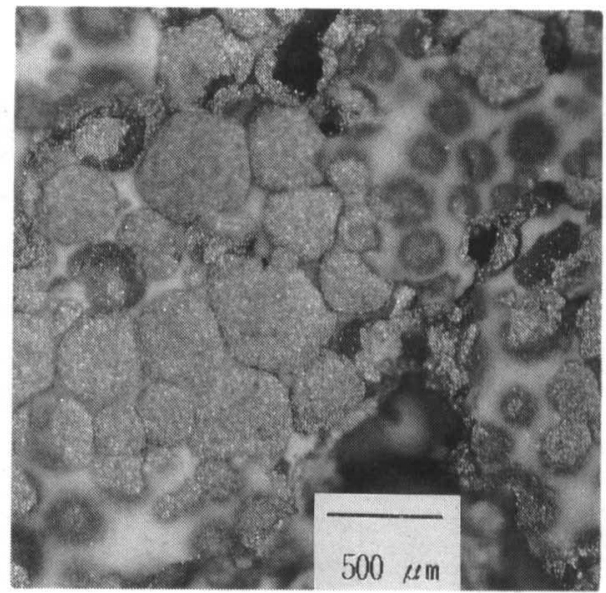

Photo.7 Optical micrograph of surface of metal layer.

本試験を進めるに当たり，烧結体の電子顕微鏡観察， $X$ 線回折測定，原料粉末の特性評価等につきまして援助 を戴きました，高木博正，倉橋利明，塩津兼一，置田ゆ かり，林るみこ，宇佐見妙子，岩田篤子，押村高明，榺 代 泉の各氏に感㥪します。

\section{文献}

1) 菅沼克昭：NEW CERAMICS, 10 (1995) 1.

2) Sun, Z:Int.J. Materials and Product Technology., 10 (1995) 16.

3) W.Wlosinski: Int.J. Materials and Product Tech nology., 10 (1995) 152.

4) S.Fukumoto, A.Hirose and K.F.Kobayasi:Composi tes Engineering., 5 (1995) 1081.

5) H.Hao, Y.Wang, Z.Jin, X.Wang:J.Materials.Science., 30 (1995) 4107.

6) 片田直伸, 石黒英明, 丹羽 幹: 日本化学会1996年 春期（第70回）年会講演要旨(1996) p.558. 